\title{
The installation of Prince Mangkubumi Performing Javanese history
}

\author{
ELS BOGAERTS
}

\begin{abstract}
Representation of Javanese history in performance plays an important role in the self-characterization of the Special Region of Yogyakarta. It legitimizes the power of the rulers and strengthens the identity of the city and its inhabitants. The audiences know the stories and this is part of the fun. In the study of oral traditions it is essential to take these performances into account. In the stories featuring famous political figures from the history of Mataram and Yogyakarta, there is an intricate relationship between the written and the spoken word: all are based on both oral and written traditions and are performed "orally". Prince Mangkubumi, who was to become the first sultan of Yogyakarta in 1755, is one of the historical personages who are protagonists in various performance genres. Focusing on the tale of Prince Mangkubumi's accession to the throne, I shall reflect on how the televised kethoprak version combines a (written) text with a mediated (aural/visual) performance to present the story.

KEYWORDS

Storytelling; performative art; intermediality; common ground; written text; script; tembang macapat; kethoprak; oral performance; television; Sultan Agung; Prince Mangkubumi; Sultan Hamengku Buwana IX; Java; Javanese.
\end{abstract}

\footnotetext{
ELS BOGAERTS lectured at Leiden University, and co-ordinated the research programme "Indonesia across Orders; The reorganization of Indonesian society, 1930-1960" at the Netherlands Institute for War Documentation, and other academic programmes. She has published about culture and decolonization, the effects of cultural encounters, and performing arts, and has (co-)edited several volumes. Her publications include: "'Whither Indonesian culture?' Rethinking 'culture' in Indonesia in time of decolonization" (in: Jennifer Lindsay and Maya H.T. Liem (eds), Heirs to world culture; Being Indonesian 1950-1965, pp. 223-253. Leiden: KITLV Press, 2012) and Recollecting resonances; Indonesian-Dutch musical encounters (with Bart Barendregt, Leiden: Brill, 2013). She has been studying representations of Javanese culture on Indonesian television. Els Bogaerts may be contacted at: bogaerte@xs4all.nl.
} 


\section{INTRODUCTION $^{1}$}

On 17 August 2015, the city of Sragen in Central Java celebrated Indonesian Independence Day with a performance of the colossal drama Pangeran Mangkubumi (Widodo 2015). Professional actors and enthusiastic amateurs joined forces to re-enact the story of Prince Mangkubumi's struggle against the Dutch occupiers. The spectacle was the result of a cooperation between members of the Sukowati Association of Traditional Artists (Asosiasi Seniman Tradisional Sukowati, Asitras) and senior high school pupils. They had chosen this story because of its intimate link to the founding history of Sragen.

Sultan Agung, Prince Mangkubumi's forefather, has also featured in a kethoprak ${ }^{2}$ performance earlier in the same year. In one of their monthly performances, the Union of the Ketoprak Mataram Artists of the Radio Republik Indonesia (Persatuan Seniman Ketoprak Mataram Radio Republik Indonesia, RRI) presented the play (lakon) Kembang Wijayakusuma, ${ }^{3}$ directed by Bondan Nusantara, a well-known Yogyakartan kethoprak script writer, director and actor. A cooperation with the Cultural Service of the Province of the Special Area of Yoygakarta (Dinas Kebudayaan Provinsi Daerah Istimewa Yoyakarta) the performance received support from senior and junior members of the Association of Kethoprak Artists and Performers (Perhimpunan Seniman dan Pelaku Ketoprak, Puspaka) and the Artists Association of the City of Yogyakarta (Paguyuban Seniman Kota Yogyakarta, Pastika).

Sultan Agung, who ruled the Central Javanese kingdom Mataram from 1613 to 1646, is one of the Javanese historical figures who, in the course of time, have emerged as the heroes of a glorious, mythologized past. He was the grandson of Senapati, founding father of the Central Javanese kingdom of Mataram. Prince Mangkubumi, who was to become the first sultan of Yogyakarta in 1755 and reigned until 1792, was another hero cut from the same cloth. They are both an intrinsic part of the collective memory of the Javanese of Yogyakarta, and have achieved immortality in folk tales and court traditions, transmitted both orally and in written form.

Stories about the heroic lives and deeds of both sultans have been told in various performance settings and genres and have been employed for various purposes. Initially, the recitation of the poetic versions of these stories was restricted to aristocratic audiences, lending the nineteenth-century Javanese manuscripts a vocal dimension. In the twentieth century, the sultans frequently

1 This article is based on my research into representations of Javanese culture on Indonesian television. I would like to thank RM Kristiadi (TVRI Jogja) for providing me with a copy of the television programme Pangeran Mangkubumi wisuda, Bondan Nusantara for the copies of several scripts of the play, and both for the wealth of information they kindly gave to me during several interviews.

I would like to heartily thank Clara Brakel for her valuable comments on the draft of this article and Rosemary Robson for editing the English.

2 Note on the spelling: kethoprak follows the transliteration of the word in Javanese spelling, ketoprak is more often used nowadays. The differentiation between the Javanese tha and $t a$ is no longer used.

3 On 3-6-2015 at the RRI Auditorium in Yogyakarta (Yudha SJ 2015 a, 2015 b). 
featured as characters in popular drama, dance and film, as well as in radio and television series. The tales were visualized or, in the case of radio, made audible but leaving their visualization to the imagination of the listeners. This tradition is still very much alive; stories about both figures are regularly staged, both in Yogyakarta and elsewhere in Java.

In all these stories there is an intricate relationship between the written and the spoken word: all are based on both oral and written traditions but are performed "orally". They include the sung performance of handwritten poetic texts; the evocation of a story whose basis derived from old court manuscripts through movement and sound; and storytelling by means of acting and televisual techniques, combining written scripts with improvisation. When studying oral traditions, these performances must on no account be overlooked.

Representations of the sultan as a founding father and a heroic figure combine history and myth. Recurring themes are the sultan's links to the ancestors; his bond with Nyai Lara Kidul, Queen of the Southern Ocean, embellished by the dance and music which symbolize their meeting; the quests in search of spiritual strength; the confrontation with and struggle against the Dutch; and his accession to the throne after the royal titles had been bestowed. Learning these stories, audiences are made aware of the heroic life and deeds of the future king and his inherent royal qualities.

In this article I shall present an analysis of the televised kethoprak Pangeran Mangkubumi wisuda by TVRI Stasiun Yogyakarta in 1993. Before examining this broadcast, I think it necessary to discuss some of the concepts which have framed my approach. Then, I shall give a short introduction to the genre kethoprak and to mediated kethoprak. After I have provided a synopsis of the story, I shall explore the way the tale is told in the television show and delve into the intermedial character of this televised performance.

My analysis will reveal that there is more than just an intermedial relationship between the script and the performance, between the television script and the television programme, and between the kethoprak performance as a dramatic medium and the medium of television. My contention is that the purport and meaning of an individual performance do not stand alone. They have invariably been enriched by preceding live and mediated performances of the same story. Furthermore, the parallels between the 1993 TVRI Yogyakarta version of the enthronement of Prince Mangkubumi and stories about both Mangkubumi's predecessors (for instance, Senapati and Sultan Agung) and his descendants (for instance, Sultan Hamengku Buwana IX) open the door to another kind of intermediality. As a whole, they form a Yogyakarta performative art tradition.

\section{Mediated performative art}

Before focusing on the practices of the storytelling, in order to frame my approach, I would like to reflect briefly on the terms performance, mediation and intermediality. Following Richard Bauman, performance is a "mode 
of communicative behaviour and a type of communicative event", usually suggesting "an aesthetically marked and heightened mode of communication, framed in a special way and put on display for an audience" (Bauman 1992: 41). ${ }^{4}$ Bauman (1984) and Finnegan (1992) refer to this display of heightened verbal expression using the term "verbal art". Despite the fact that Finnegan says that most scholars use it in its wider meaning referring to the performance in its entirety (Finnegan 1992: 10-11), I prefer to use the term "performative art" rather than "verbal art", as the latter term lays too much emphasis on pure verbality.

The examples in this article show an intricate and unique relationship between the (aural/visual) performance and its (written) textual counterpart. I view the former as the actual presentation and the latter as pertaining to the field of "capacities, models, or other factors that represent the potential for such an action or an abstraction from it" (Bauman 1992: 41). But, contrary to Bauman, I do not perceive an opposition between these two forms of mediation, consisting of the actual presentation (the performance) and the potential presentation (the text). I prefer to see these forms as mutually inclusive; the narration in the one medium exists only because of the other. At present, in analyses of such translational processes from the one medium into the other, the term intermediality tends to prevail..$^{5}$ I shall follow Wolf's definition of intermediality "as a particular relation (a relation that is 'intermedial' in the narrow sense) between conventionally distinct media of expression or communication: this relation consists in a verifiable, or at least convincingly identifiable, direct or indirect participation of two or more media in the signification of a human artefact" (Wolf 1999: 37). Chapple and Kattenbelt (2006: 12) point out the historical association between intermediality and "the exchangeability of expressive means and aesthetic conventions between different art and media forms". I shall reflect briefly on the intermediality between the televised kethoprak performance and its written potential, on other versions of the Pangeran Mangkubumi wisuda story and on related narratives. I will however mainly focus on the way in which the story is told in the televised version of the story.

\section{Kethoprak}

Kethoprak is a Javanese dramatic performance genre which evolved in the late nineteenth century. In the 1920s, its development began to betray the influence of European theatre and film. In its new shape, it embodied features of the wayang tradition, the folk tradition and the modern theatre (Vaníčková 1965: 414). It is performed on a stage by actors and is accompanied by a gamelan orchestra and male and female singers. Traditionally beating on a keprak

4 See Schechner on performance: "Behavior heightened, [...], and publicly displayed" (Schechner 1993: 1). See also Finnegan on forms of "heightened verbal expression" (Finnegan 1992: xiv).

5 See, for instance, Chapple and Kattenbelt (2006) for an overview of the use of this term. 
or kenthongan, small wooden slit drums (Kunst 173: 192-193), was used to mark either the beginning or the end of the scenes, to stress an action or strong emotion during the performance and to accompany particular dance movements. It also gave the gamelan players a signal to commence or stop playing or switch to another melody or rhythm. It was the cue for the actors to enter and leave the stage. Present-day performances tend to omit the use of the keprak. The themes can be drawn from Javanese legends and history, or from Javanese interpretations of Indian and Middle Eastern stories. The dialogues are spoken in contemporary Javanese, and are couched in a typical vocabulary and prosody.

At the end of the nineteenth and the beginning of the twentieth century, one of its most notable features, no doubt affected by the dynamics introduced by the many and varied troupes in Southeast Asia, was a mutual dissemination of ideas and influences between the urban popular theatre forms. Consequently kethoprak shares common characteristics with other forms of urban popular drama in Southeast Asia, which were "entertainment-oriented and highly commercial" (Tan Sooi Beng 1997: 18). Among these theatrical genres are the Malayan bangsawan, the zarzuela of the Philippines, the likay of Thailand, the lakon bassac of Cambodia, the cai luong of Vietnam, the komedi stambul of the Netherlands East Indies, the ludruk of East Java, the sandiwara or tonil of West Java (Tan Sooi Beng 1997: 18) and the Balinese drama gong.

However, although kethoprak was indubitably influenced by different cultures (and can be considered a hybrid form) and has inevitably incorporated elements of these, its essential character is still perceived to be Javanese. Vaníčková calls kethoprak "essentially a Javanese affair". The author, who conducted her research on kethoprak in 1961-1962, stated that, "[i]t has its roots in the Javanese milieu and is performed in Javanese, by Javanese, for Javanese" (Vaníčková 1965: 398). Geographically, it is one part of the cultural heritage of Central Java. More specifically, Yogyakarta has become "the" centre of kethoprak. To such an extent that Hatley has stated that, since the early twentieth century, this popular theatre form became explicitly identified with the city (Hatley 2004: 66), and kethoprak activities in the area of Yogyakarta have influenced the standards and stylistic models of the genre in other areas (Hatley 1985: 7). In 1957, the first national kethoprak festival and congress were held in Yogyakarta (Yuliantri and Dahlan 2008: 339-340). Despite the presence of famous touring kethoprak troupes from East Java (Siswo Budoyo and Wahyu Budoyo) and Surakarta (Kethoprak Cokrojio), the image of kethoprak is that of a quintessential part of the cultural landscape of Yogyakarta.

Kethoprak has a long history of political involvement. During the colonial period, it was used as a medium to stir the national consciousness of the people in the struggle for an independent Indonesia (Kus Sudyarsana, 1984/1985: 59). In the independence period, kethoprak actors in specific troupes used their performances as a vehicle for political satire. In this environment of change, the old repertoire was adapted to the purposes of nationalist propaganda and the ongoing saga of political struggle (Vaníčková, 1965: 414). Pertinently, for 
ideological purposes the communist-oriented Lekra (Lembaga Kebudajaan Rakjat) had a serious interest in kethoprak. ${ }^{6}$ Moreover, the New Order government also did not hesitate to disseminate information and propaganda by means of kethoprak and other traditional performing arts genres.

\section{Mediated kethoprak}

The use of electronic mass media as a vehicle for the dissemination of local cultural expressions began in the 1930s, when gramophone recordings and live performances of local music were broadcast by the newly established radio stations. The listeners were spell-bound by the new technology of radio: the "transmission of real performance in real time" was a fascinating novelty and it offered a sense of immediacy of communication between physically disconnected performers and listeners; a band reinforced by the familiarity of the content of the radio broadcasts - "music of the listener's own locality" (Lindsay 1997: 108-109).

In 1935, the Mataramsche Vereeniging Voor Radio Omroep (MAVRO) Yogyakarta broadcast a kethoprak performance by the troupe Krido Rahardjo (Wijaya and F.A. Sutjipto 1977: 44). The performances by this troupe became part of the standard MAVRO radio broadcasts during what remained of the colonial period (Mardianto and Darmanto 2001: 96-97).

Acting for radio required adaptations which would aid the listeners' visualization of the performance: all attention was concentrated on the evocative strength of the voice and the music. In tune with the aural character of radio, Krido Rahardjo - after independence called Ketoprak Mataram RRI Yogyakarta - , began to perform using written dialogues. ${ }^{7}$ A real novelty was the use of the voice as a means to convey dramatic expression, while the length of the dialogues was extended concomitantly and the use of and playing with language were taken to new levels. The accompanying music was complemented by sound effects. Also, some of the principles of western dramaturgy were introduced to reinforce the basis of kethoprak. The performances worked towards a climax and the contents of the dialogues were attuned to the theme of the lakon. Another innovation was the presentation of foreign stories - Hamlet was adapted to a Javanese lakon, for instance (Kus Sudyarsana 1989: 36).

The weekly kethoprak broadcasts by the local radio station RRI Nusantara II Yogyakarta were transmitted live, following in the footsteps of the MAVRO broadcasts (until 1942) and the Hoso Kyoku during the Japanese occupation. The performances took place in the studio and were conceived to fit the constraints of the medium radio. Therefore live broadcasts required the full concentration and creativity of the director, the actors and musicians. One of these constraints was on-the-spot adaptations. If, for instance, the 22.00 news

6 In Lekra tak membakar buku, Rhoma Dwi Aria Yuliantri and Muhidin M. Dahlan show how Lekra appropriated the dramatic genre for ideological purposes, as reported on in Harian Rakjat (Yuliantri and Dahlan 2008: 339-353).

On the use of script in Javanese theatre performances, see Bosnak 2006. 
bulletin ran over time, the time slot available for the play had to be cut short. In order to finish the whole story in time and not to upset the climax, there had to be impromptu condensations of dialogues (Mardianto and Darmanto 2001: 96-136).

At present, the Yogyakarta RRI presents live broadcasts of monthly performances for a public in the RRI studio; my example mentioned at the beginning of this article refers to such a broadcast.

From the 1970s, popular music and local dramatic genres, including kethoprak, were recorded on cassettes, both to be sold either as a commercial product or to be broadcast on radio. The cassette industry tended to be more selective than radio in that it only presented the top range of performers (Sutton 1985: 26), whose prestige and power flourished in the wake of the popularity engendered by these recordings (Sutton 1985: 40). This dissemination of local performing arts genres on cassettes had one very important consequence: it facilitated imitation, standardization and homogenization (Sutton 1985: 25). Nevertheless, it did not expunge diversity (Sutton 1985: 26).

The introduction of cassette tapes encouraged the broadcasting of kethoprak by private radio stations. Even in places without electricity, tape recorders and radios run on batteries enabled people to listen to cassettes and broadcasts of traditional performing arts. Although some kethoprak troupes hailed the advent of the cassette industry, others considered it detrimental, because one of its side-effects was a decline in live performances. The validity of this point can be disputed on the grounds that the tapes were popular precisely because they contained recordings of well-known troupes; therefore their audiences were even more keen to attend a live performance of this troupe. Consequently, Wijaya and Sutjipto conclude that modern technology was unquestionably a useful tool in boosting the art of kethoprak (Wijaya and F.A. Sutjipto 1977: 44-45).

Not long after the launch of TVRI in August 1962, traditional performing arts had already become an important item in its programming. One of the main goals set by Televisi Republik Indonesia was to disseminate and preserve national culture. Therefore, the programmes of both the Jakarta-based national and the regional government-owned television stations featured cultural programmes as quite a large percentage of their daily broadcasts. Although the reasons regional performing arts programmes were allotted a significant position in the broadcasting schedules of both the national (TVRI Jakarta) and the regional government television stations might have been several, the fact that broadcasts of Javanese drama were assigned a fair amount of scheduling time by the regional television stations TVRI Stasiun Yogyakarta ${ }^{8}$ and TVRI Stasiun Surabaya ${ }^{9}$ certainly hence played an important part in promoting these genres. Later, private television stations broadcast kethoprak for commercial reasons. From 1995 onwards Indosiar tried to win the hearts

TVRI Stasiun Yogyakarta was established on 17 August 1965.

TVRI Stasiun Surabaya was established on 3 March 1978. 
of the Javanese, the largest potential consumer market, with broadcasts of traditional Javanese theatre genres including kethoprak. Since 2002, local Javanese private broadcasters have focused on local genres such as wayang kulit and kethoprak. ${ }^{10}$

Not all was plain sailing. Broadcasts of kethoprak on television once again confronted the kethoprak performers with new challenges. Bondan Nusantara has noted that the first kethoprak programme was broadcast in 1965, a time at which only a few troupes could be televised: Kethoprak Budi Rahayu, Dahono Mataram, Sapta Mandala, Eko Budoyo, Among Mitra and PS Bayu (Bondan Nusantara 1990: 43). Although Bondan Nusantara does not explain his statement, it is reasonable to assume that, in the light of the contemporary upheavals in the political situation, many kethoprak actors had either been killed or imprisoned in the resultant turmoil or, at the very least, had been banned from performing.

In 1977 during a seminar on kethoprak in Yogyakarta organized by the Department of Education and Culture, when a young actor was requested to specify the point of climax in the play Arya Penangsang Gugur, the following happened:

The actor looked puzzled and embarrassed and finally replied that it depended on how many nights were to be taken to present the story! To him the lakon represented not a fixed dramatic whole with a key point of climax but a more fluid entity, shaped by the contingencies of the performance. If necessary it could be divided into several sections, performed on separate nights, each section ending sufficiently climactically to draw viewers back for the next night's performance. (Hatley 1985: 112.)

As Hatley goes on to show, several other factors can play a part in shaping the progression of a live show: for instance, the late arrival of certain performers or the over-extension of particular scenes and routines. Actually, although this anecdote refers to a live/non-televised performance, it does betray the characteristics of a televised kethoprak performance, in which exactly the opposite is happening.

Cogently Bondan Nusantara distinguishes three kinds of kethoprak performances broadcast on television: kethoprak for television; kethoprak on television; and television kethoprak (Kus Sudyarsana and Bondan Nusantara 1990: 41, 55; Bondan Nusantara 1991: 42). ${ }^{11}$

As examples of the first kind, kethoprak for television, Bondan Nusantara gives the kethoprak fragments broadcast within the framework of regional news programmes (berita daerah) or in programmes focusing on Javanese culture. Kethoprak on television, his second category, consists of broadcasts of kethoprak performances which would have taken place irrespective of

\footnotetext{
10 See Bogaerts (Forthcoming).

11 "Wonten tigang jenis Kethoprak ingkang dipun-tayangaken televisi. Injih menika Kethoprak kangge Televisi, Kethoprak ing Televisi saha Kethoprak Televisi [...]" (Bondan Nusantara 1990: 55).
} 
television. These broadcasts might be live or else consist of pre-recorded, edited kethoprak performances in the studio. When the Yogyakartan TVRI station created kethoprak sayembara, serialized kethoprak which included a prize-winning contest, Bondan Nusantara postulates this marked the birth of the third category, television kethoprak: created for especially the television medium and existing only on television.

In 1988, TVRIStasiun Yogyakarta broadcast the first kethoprak serial, Prahara, based on a script by the novelist Singgih Hadi Mintardja and performed by Sapta Mandala Kodam IV Diponegoro directed by Bagong Kussudiardja. In spite of the fact that various artists did regard this broadcast as the initiation of kethoprak televisi, others were adamant that the serial Prahara was no longer worthy of the name kethoprak, as it failed to replicate the traditional constraints of the genre ("sawetawis pakulinan (tradisi) Kethoprak") (Bondan Nusantara 1990: 44).

Most kethoprak productions broadcast by Yogyakarta TVRI in the 1990s did go beyond mere televisualizations of live performances. Recorded either in a studio setting or outdoors, these productions did deviate from the traditional live performances on a stage using backdrops, in the presence of an audience, in which lengthy dialogues were improvised. TVRI kethoprak was a genre conceived for the medium television: because of the directness of the images, long-drawn-out dialogues were made superfluous; improvisation was restricted because of the restraints imposed by scenarios and scripts whose content was dictated by time limits and censorship; the scenes were condensed and reduced to the essentials; the acting, the costumes and the make-up had been influenced by modern drama and tailored to the circumstances and television techniques available in that studio; and any direct audience response was eliminated since people were not usually present during studio recordings. ${ }^{12}$ In short, the performance had been adapted to the constraints of the medium and the aesthetics had been adapted to those dictated by television.

In the early 1970s, although kethoprak by amateur and professional troupes was broadcast weekly by TVRI Yogyakarta, radio stations were broadcasting the dramatic genre on an almost daily basis (Hatley 1985: 11). This media exposure led to a greater accessibility to various kinds of drama. Williams has drawn attention to this evolution. His contention is that television in most parts of the world changed the scale and intensity of dramatic performance drastically, causing "a majority of any population [to have] regular and constant access to drama, and us[ing] this access" (Williams 1994: 59). In the wake of their increasing reach, the media not only made drama "an intrinsic part of everyday life" (Williams 1994: 59), kethoprak was now brought to the attention of people in social classes beyond that of the wong cilik, farmers, and labourers, in whose circles kethoprak is said to have originated. This assertion has been confirmed

12 Habib Bari, oral communication, Yogyakarta, 14-08-2001. Darma Putra (1998) mentions similar characteristics of mediatized Balinese drama gong. 
by the study of Umar Kayam and his fellow researchers, who conclude that the electronic mass media have made traditional performing arts more accessible to people from different social layers (Kayam et al. 1985/1986, 2000). Sedyawati (1981:39) calls this a shift in ownership. Hatley has also pointed out the effect of the television broadcasts on the broadening of kethoprak audiences because, once broadcast, the genre received "increased attention from and contact with people of some education and status" (Hatley 1981: 40-41, 1985: 13).

After this lengthy introduction to the mediating of kethoprak, I should now like to turn to the televised play Pangeran Mangkubumi wisuda and analyse its structure.

\section{Pangeran Mangkubumi wisuda: televised kethoprak}

In 1993 TVRI Stasiun Yogyakarta produced a kethoprak version of the story of the accession to the throne of Prince Mangkubumi as the first sultan of Yogyakarta. It broadcast Pangeran Mangkubumi wisuda (The installation of Prince Mangkubumi) in two episodes, on 20 September and 11 October.

That same year, the story of Prince Mangkubumi's elevation was also staged in Yogyakarta on several occasions. In January 1993, ${ }^{13}$ the group Sapta Mandala performed the play in the sultan's palace ${ }^{14}$ to commemorate the founding of the Mataram court by Prince Mangkubumi, later Sultan Hamengku Buwana I. Soedarsono (1993) has claimed this was the first occasion on which the reigning sultan of Yogyakarta had allowed the representation of Javanese court history in kethoprak, "a humble people's theatre" (Hatley 2005: 75), within the palace walls. Built by the first monarch, for centuries this palace had been a political centre. However, in the 1990s in its role as a centre of traditional Javanese culture, the staging of dance and theatre other than court genres was unusual. The 1993 kethoprak performance was presumably an allusion to the reigning sultan of Yogyakarta, Sultan Hamengku Buwana X, as it depicted Mangkubumi as a wise leader who enjoyed a close relationship with his people (Hatley 2008: 169).

In September 1993, members of the Gadjah Mada University Art Unit (Sekber Unit Kesenian UGM Yogyakarta) performed the lakon in the Balairung university building (Utami 1993: 11), another historical location, to celebrate the foundation day of the Gadjah Mada University. It was a televisual adaptation of this version of the performance, which TVRI Yogyakarta recorded and broadcast in September and October that same year. ${ }^{15}$ The purpose of the recording and the broadcast was to offer the people (masyarakat umum) the opportunity to enjoy the Balairung performance ${ }^{16}$ which had been staged for an invited audience.

Bondan Nusantara directed the three versions of the play, all based on

13 On 16 and 17-1-1993.

14 In the Pagelaran Kraton.

15 Hatley (2008: 168-169) suggests that the three performances of the lakon were all staged by Sapta Mandala actors, but according to the data I obtained, this was not the case.

16 Oral communication Bondan Nusantara 2-7-2012. 
an adaptation of a script written by the well-known and influential kethoprak innovator, actor and playwright Kus Sudyarsana. ${ }^{17}$ I have not yet been able to trace Kus Sudyarsana's original script, the date of writing or the occasion for which he conceived it. My search for a copy of the script which was used for the 1993 television performance has been to no avail. Recently I encountered a photocopy of a script by Kus Sudyarsana in a reworked version (dipun rakit malih) by Bondan Nusantara. ${ }^{18}$ The copy is undated. Most likely it was used for the January 1993 performance in the Yogyakarta kraton - it contains references to the sultan's palace as performance location. The division into scenes and the dialogues approximate those of the 1993 TVRI version very closely, and the stage directions also lead to the same conclusion. It is this script ("the 1993 palace performance script") to which I am referring in my exploration in this article.

The central theme of all these Pangeran Mangkubumi stories is the enthronement of Prince Mangkubumi. The main events leading to this climax are the following: Chief Councillor Pringgalaya who sides with the Dutch persuades Susuhunan Paku Buwana II to sign an agreement with the latter. Upon hearing news of this capitulation, Paku Buwana's younger half-brother Prince Mangkubumi decides to take up arms against the Dutch, but he refuses absolutely to rebel against the king, his liege lord. Mangkubumi and his soldiers attack the Dutch headquarters (loji). When news of this assault reaches his ears, the monarch collapses. Prince Mangkubumi is installed on the throne as the first ruler of Yogyakarta, Sultan Hamengku Buwana I. Although this theme runs through all the versions of the story, each individual performance offers a different approach and different presentation of the story. I shall elaborate briefly on a few variations in the paragraph concerning intermediality in this article.

The lakon of the 1993 television version, a reworked version of Kus Sudyarsana's script, presumably based on a Javanese court chronicle (such as, the Babad Giyanti or the Serat Babad Mangkubumi) and oral literature, is unquestionably based on historical fact. Several rebellions against the vacillating Javanese ruler, quarrels with the Chinese, problems over land and Dutch interventions in internal politics led to the division of the Central Javanese kingdom into the courts of Surakarta and Yogyakarta in 1755. Pangeran Arya Mangkubumi, the half-brother of Susuhunan Paku Buwana II of Surakarta, was acclaimed the first sultan of Yogyakarta. On account of the resistance he offered his halfbrother and the Dutch and his emergence as victor from the resultant struggle, he is depicted as a hero and the founding father of Yogyakarta. ${ }^{19}$

17 Also spelled Kusudyarsana or Kus Sudyarsono. See MS 1991a, 1991b; MS-Warso Sastrosuwarno 1991; Lephen P. 1991. Handung Kus Sudyarsana also was a journalist at the Yogyakartan local newspaper Kedaulatan Rakyat.

18 This photocopy of the script is kept in the library of the Studio Teater PPPG Kesenian (PPPPTK Seni dan Budaya) in Yogyakarta. I am very grateful to Eko Ompong Santosa who sent me a digital copy of the text.

19 Ricklefs gives a detailed account of the Dutch intervention in Javanese affairs in the 
The theme belongs to a series of very popular motifs, namely: the struggle of members of the aristocracy in collaboration with the people to achieve both independence from the Dutch and the instigation of a righteous rule by the Javanese monarch. Brandon has remarked that this theme - "depicting the evils of the enemy and the virtues of the local hero" - is not confined to Javanese kethoprak, but is a constant in other dramatic genres in what he calls the popular tradition, both in other Indonesian and other Southeast Asian cultures. Brandon emphasizes the plays "appeal to nationalistic sentiments" (Brandon 1974: 103).

This lakon belongs to the so called kejawen stories, which kethoprak participants state constitutes the core repertoire of the genre (Hatley 1985: 54). Hatley points out their "inherent Javaneseness" as they are "rooted in Javanese history, attired according to traditional, ongoing Javanese dress convention" (Hatley 1985: 54).

\section{Structuring the story}

Pangeran Mangkubumi wisuda was broadcast in two 55-minute episodes. Each episode consisted of a series of scenes (babak), defined by the locale in which the action took place, the characters present and the mood/atmosphere (swasana) of the scene. The 1993 palace performance script notes these parameters for each consecutive scene and contains stage directions (katrangan) for the director and the performers.

In most traditional kethoprak performances, each scene is given form in a specific setting. Painted backdrops and stage props are used to represent the locale in which the action is taking place. In the broadcast of Pangeran Mangkubumi wisuda, this was not the case. The setting was a plain stage, with several platforms, one of them consisting of a series of tiered daises in the stage centre back, all black. The central platform had a cube on top, a curved back "wall" and was topped by a royal umbrella. The mise en scène was very simple and abstract. The lighting was simple: a red glow behind the central platform; the stage plainly lit with white light. With the exception of the most important elements, such as the royal umbrella, two lances and a magic whip, no properties were used. Other conventions belonging to traditional kethoprak, such as the use of a keprak or kenthongan, had been omitted, and the use of singing (tembang) instead of a dialogue to convey a message was limited. Such simple and abstract staging is exemplary of one of the typical kethoprak styles of TVRI Yogyakarta. No audience was present in the studio during the recording of the play. However the musicians took over part of the audiences' role in reacting to certain events on the stage.

Following the 1993 palace performance script, the story develops along the following scenes.

eighteenth century in his chapter on the rebellion and the division of the kingdom (Ricklefs 1974: 37-66). 
First episode:

Scene 1: Kraton Surakarta Hadiningrat

Mood: lofty (agung)

Present in the audience hall are Susuhunan Paku Buwana II and all those attending the audience (Patih Pringgalaya, officials and courtiers), joined by the bedhaya dancers of the Kepatihan, a marching band and the Dutch Governor-General van Imhoff. Absent is Prince Mangkubumi. Pringgalaya persuades the Susuhunan to sign an agreement with the Dutch.

Scene 2: Mangkubumen Palace

Mood: sad (sedhih)

In the female quarters, the keputren, Prince Mangkubumi's spouse Mas Ayu Asmarawati worries about her husband's absence, as he has not been to the Mangkubumen for quite a long time. Dialogue with her mother-in-law Mas Ayu Tejawati and her two ladies-in-waiting, Menur and Telasih. Ki Rangga arrives and informs the women of Mangkubumi's whereabouts in two flashbacks, switching to the Surakarta kraton.

Scene 3: Grobogan Village, Purwadadi

Mood: noisy and strident (gumyak, sereng)

In the village, male and female soldiers (prajurit) are training in preparation for the war, supervised by Ki Martapura and his son Suwandi. A woman enters, her fist raised. End of the first episiode.

Second episode:

Scene 3: Grobogan Village, Purwadadi (continued)

Fierce discussion between Nyi Martapura (the woman who made her appearance at the end of the first episode) and her husband. Pringgalaya arrives, inviting Ki Martapura to pay a visit to the Susuhunan. Suwandi slaps him in the face. Arrival of Mangkubumi, who raises the courage of the soldiers. Fight scene. Pringgalaya's soldiers flee.

Scene 4: Kraton Surakarta Hadiningrat

Mood: silent, serious (tintrim, kenceng)

Patih Pringgalaya and the Dutch Governor-General inform the Susuhunan about the latest developments in his realm. While the gong Kyai Bicak is beaten and Mangkubumi's soldiers arrive, the monarch collapses.

Scene 5: Gunung Tidhar (Tidhar Mountain)

Mood: silent, serious (tintrim, kenceng)

An old man warns Pangeran Mangkubumi that he will be in danger and gives him a whip. With this whip, Mangkubumi defends himself and wards off an attack by the enemy. When his own troops take a rest and female dancers entertain them with a tayuban dance, the atmosphere relaxes. Ki Rangga interrupts them and bids them all to follow Mangkubumi to his lodge at Ambar Ketawang. 
Scene 6: Pesanggrahan Ambar Ketawang (Royal Lodge Ambar Ketawang)

Mood: lofty (agung)

Raden Rangga enters accompanied by the soldiers, the two princesses and their servants. He reads the villagers a declaration announcing that Prince Mangkubumi is to be installed as the first sultan of Yogyakarta.

\section{Telling the story}

Although at first sight the televised play seems to be no more than a recording of a live performance, ${ }^{20}$ the storytelling has actually been adapted to the constraints of the medium television. The story is brought to life by means of the performers on stage, their acting and interaction. But, as the performance was recorded in the TVRI studio and broadcast, the camera gaze (angles and shots of the three cameras used) and the editing, with the assistance of additional sound and visual effects all guide us, the television audience, through the story. The narrative develops by means of telling (diegesis) and showing (mimesis) (Chatman 1990: 117).

In order to grasp how meaning comes into being while people watch and listen to a broadcast, recourse to Scannell's idea of "common ground" might be helpful. Common ground supposes "a shared competence" between programme makers and audiences. Scannell calls it a precondition of any kind of social interaction, a definition which also applies to mediation processes. It includes "a common cultural-linguistic competence, shared knowledges and understandings" (Scannell 1995: 13). In the present case, it also encompasses shared knowledge of the genre kethoprak, and of the narrative conventions of both kethoprak and the medium television. As the audiences are conscious of these conventions and recognize them, they have certain expectations of the show. Hence the challenge for the producers to work with this common ground in such a way as to keep the audiences glued to the television.

To reveal how the story is told, I shall present some examples of the narrative techniques used in the TVRI Yogyakarta version of Pangeran Mangkubumi wisuda. I shall delve into the presentation of the characters and the problem in the first scene; tackle the concept time by showing instances of references to the past and the future which deliberately "disturb" the chronology of the plot; cliffhangers; music and dance; and the climax of the story. To illustrate the close link between the textual and the audiovisual presentations, I shall relate my descriptions of fragments of the TVRI Yogyakarta programme to the 1993 palace performance script.

The introduction to the programme sets the tone for the entire broadcast. It offers the audiences a first glimpse of the setting and shows the opening credits, displaying the names of the major contributors to the production and the actors; people fighting on the background should arouse the curiosity of

20 The playwright/director acknowledged he kept to the concept of a staged performance (oral communication Bondan Nusantara 2-7-2012). 
the viewers. The function of this intro to the first episode is to foreshadow the coming conflict and capture the attention of the television audiences.

The programme begins with a camera close-up of a royal umbrella (songsong negara) which is closed; then the camera pans down to focus on the people fighting, slowly zooming out, while on the screen the title Pangeran Mangkubumi wisuda appears in italics, followed by the text "Seri 1".

We see silat-like fights (without weapons) between two parties, dressed in simple jackets of woven cloth (lurik), a folded batik cloth, trousers and a blangkon as headdress. The camera focuses alternately on the different duelling pairs, slowly offering an overview of the fighting scene as it zooms out. We hear the shouts of the people fighting and loud gamelan music. A male voice sings (nembang) that the story will be about Prince Mangkubumi going into battle (critanipun sang pangeran naraputra Mangkubumi ngajurit); he is preparing his troops to defend the country (ya cancut wadyanireki bela nagara).

In the first scene, which is located in the audience hall of the Surakarta palace, we make the acquaintance of the main characters in the play. They are introduced in various ways, either by taking part in the dialogue or by being mentioned or referred to.

\section{Scene 1: Kraton Surakarta Hadiningrat}

The scene lasts for about twenty minutes. The camera offers a general view of the personages attending the audience - the Chief Councillor Patih Pringgalaya, officials and courtiers - who enter the space in laku dhodhok ${ }^{21}$, their backs to the camera/the television audiences. They all focus on the central stage, and make a respectful sembah ${ }^{22}$ in front of the Susuhunan's throne.

A male character dressed in a batik jarik with a parang motive, a black jacket, wearing a black and gold kuluk on his head, a keris at his back, a royal chain and a brooch has solemnly entered the centre of the screen, his back turned to the camera/the audiences. He ascends the central platform and seats himself on the upper cube, representing the throne, in the way Javanese kings are typically depicted on thrones (as shown in the portraits of the rulers to be seen in the Central Javanese courts). Those present make their obeisance to the monarch with a sembah, then seat themselves in sila (cross-legged) on the floor, with the exception of the Patih, the king's Chief Councillor, who sits opposite the others on a single platform.

Among the cues which indicate the ranking of the characters are the body language, the position they take in the space and the costumes. The royal attire was possibly designed after painted portraits of royalty. Once the dialogues commence, the language use, the Javanese speech styles and prosody provide additional information about the position of the characters.

21 To walk in a squatting position when approaching a high-ranking personage (Robson and Wibisono 2002: 419).

22 A gesture of high esteem made to a superior by holding the hands before the face, palms together, thumbs approaching the nose, and bowing the head slightly (Robson and Wibisono 2002: 663). 


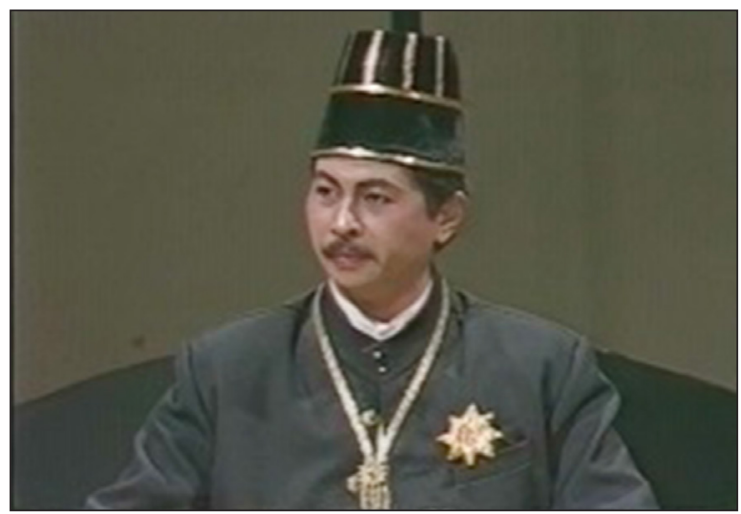

Image 1. Susuhunan Pakubuwana II acknowledges the greetings.

The dialogue following the entrance of the personages introduces them to the television viewers, offers glimpses of their characters and reveals the relationship between the protagonists and antagonists. The Javanese audiences are aware (and learn from the context offered) that the man on the throne is the Susuhunan of Surakarta, Paku Buwana II; the person opening the dialogue is his Chief Councillor, Adipati Pringgalaya. Only later in this sequence does the Sunan address him by his name. Pringgalaya pays obeisance to the ruler and commences speaking, his body language reproducing a Javanese way of speaking and gesturing while pointing with his right thumb. He reports that everybody is present at the audience in the palace of Surakarta. ${ }^{23}$ The camera provides a medium shot of Pringgalaya, alternating with shots of the others present during the session and of the king. The Susuhunan acknowledges the greetings and asks Pringgalaya whether Prince Mangkubumi has come to the meeting (Image 1). Pringgalaya answers, while making a sembah: "Kados mboten, Sinuwun" - It seems he is not present, my Lord. I do not understand why Prince Mangkubumi has not yet arrived.

Although physically absent, Mangkubumi is very much present, in Pringgalaya's vicious comments (Image 2), in the Sunan's asking if he does not know about this special meeting in Surakarta and, later, in this first scene, when Governor-General van Imhoff discusses Mangkubumi's land in Sokawati with the Sunan. We only see and hear Mangkubumi himself from the second scene onwards. Governor-General van Imhoff's arrival upon his turn is announced by Prince Anggawijaya.

23 "Ngestokaken dhawuh timbalan dalem, para pengeran, pengeran putra, sentana, bupati nayaka tuwin wadu wandawaning praja nuwun injih sampun ngabyantara wonten ngarsa dalem. Sedaya sami ngunjukaken sembah bekti konjuk pepada Dalem". Pringgalaya makes the sembah while saying this. 


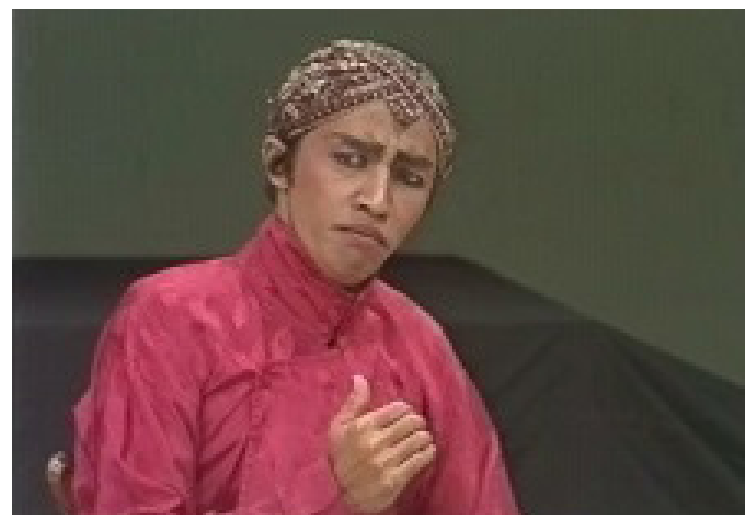

Image 2. Pringgalaya criticizes Mangkubumi's absence.

Most stage directions in the script, which was very probably written for the January 1993 Sapta Mandala performance in the sultan's palace, were adopted for this televised performance. In the first scene, ${ }^{24}$ they indicate which characters enter the space, how and why, their position on the stage (according to their ranking), how they pay obeisance to the throne before sitting crosslegged and so on; the entrance of the monarch, his sitting enthroned; Patih Pringgalaya opening the communication. The references to the locations in the Yogyakarta palace were of course not used in the TVRI version; nor in this version was the Susuhunan escorted by his female attendants carrying the regalia.

The dialogues neatly follow the script which, because of the time constraints of the medium television, offers no room for improvisation, one of the most attractive characteristics of a non-mediated kethoprak performance.

The central problem, which leads to the conflict and propels the drama forward towards the climax in the last scene, is also revealed in the first scene. Van Imhoff explains to the Susuhunan the reason for his visit. He has come to present him with the letter of agreement (serat perjanjen) they had talked about a while ago. Using the Patih as a mediator, he gives the letter to the Susuhunan. When the Susuhunan is very hesitant about signing the agreement, Patih Pringgalaya urges him to do so, reminding him that the Dutch had always helped him in the past. Furthermore, the treaty will not only benefit the Dutch, it also takes account of the wellbeing of the Susuhunan and the whole of Surakarta, not to mention guaranteeing the continuation of his reign. Although one of the Susuhunan's advisers is negative about the

24 1. Para Pangeran, para Tumenggung, Patih Pringgalaya lampah dhodhok, sowan. Dumugi papanipun piyambak-piyambak (laras kaliyan kalenggahan saha pangkatipun) lajeng sami jengkeng, nyembah, lenggah sila marikelu wonten plataran ngajeng Siti hinggil, wingking Pagelaran Kraton Ngayogyakarta.

2. Nalika sadaya sampun sumekta, Sampeyan nDalem Ingkang Sinuwun Pakubuwono II miyos, kairing para emban cethi manggung biyada banyak dhalang sawung nggaling. Ingkang Sinuwun lenggah dhampar.

3. Patih Pringgalaya munjuk. 
Dutch proposal, the ruler is obliged to acquiesce Van Imhoff's proposal and gives in. It is this treaty which, as we shall see in the second scene, rouses Prince Mangkubumi's anger, thereby heightening the dramatic tension and propelling the progression of the story.

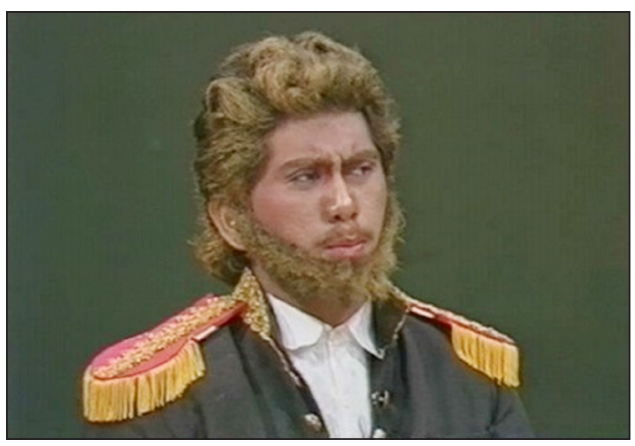

Image 3. Governor-General van Imhoff.

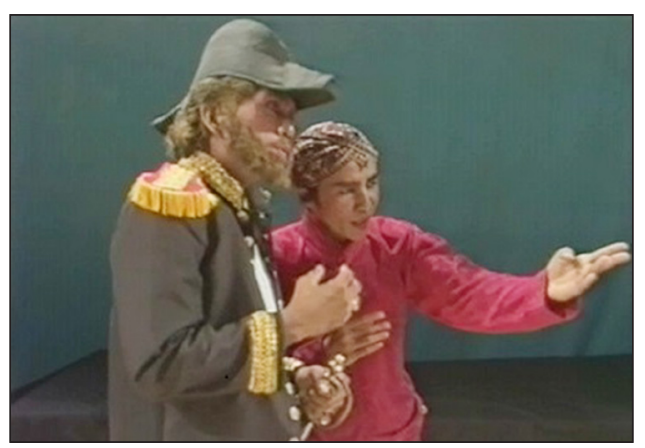

Image 4. Pringgalaya and Van Imhoff exchange an aside.

While the gamelan is playing softly, the camera focuses on Pringgalaya and Van Imhoff who are exchanging an aside - we do not hear their conversation (Images 3 and 4). Van Imhoff then approaches the Susuhunan and urges him to make haste, which makes the Susuhunan angry.

Pringgalaya, who agrees with Van Imhoff's proposal, lists all the past events in which the Dutch helped the Susuhunan. Furthermore, he proposes that Mangkubumi's land in Sokawati be reduced by two-thirds (dipun suda 2,000 karya) to prevent the other princes from becoming jealous and querying the Susuhunan's sense of justice. Van Imhoff asks the Susuhunan to return the treaty to Pringgalaya after he has signed it.

The Susuhunan apparently agrees. He bids the two men to leave the hall, showing them the way (but actually leaves the stage himself, leaving the two men behind, a theatrical device which could have been solved with televisual means. But as this is a broadcast of recorded drama which was performed on stage, the theatrical technique was retained.).

Various narrative techniques are used to intervene in the chronological order of the story. One example is the conveying of past happenings, which culminate in the events presented in the play. In the discussion between the Susuhunan, Pringgalaya, and Van Imhoff, references are made to past events which the Dutch claim present reason for a treaty: the Chinese uprising, Raden Mas Said's rebellion, and Prince Mangkubumi's grant of the land of Sokawati because he defeated the rebel troops of Raden Mas Said. ${ }^{25}$ A reference to a dream predicting the divide between Raden Mas Said and Prince Mangkubumi occurs in the second scene. Another device to refer to events which have taken place in a different time and space is the flashback. The example I shall present here shows how the main storyline functions as a frame in which to present 
another story: Ki Rangga relates what he heard from Prince Mangkubumi; Mangkubumi's account is presented as a flashback. The flashback functions as a kind of direct speech in the narration, and plays upon different temporal realities in the narrative. Thanks to device of parallel montage, cutting back and forth between separate locations (Kozloff 1992: 85), we witness happenings taking place in different spaces.

The second scene is located in the female quarters of the Mangkubumen palace. It follows the dialogues and stage directions in the 1993 palace script closely, with the exception of the directions for the setting - in the script the latter refer to how matters stand in the sultan's palace, the location of the January 1993 performance.

\section{Scene 2: Mangkubumen}

The camera focuses on a part of the set which until this moment in the broadcast has remained invisible to the television audiences and is located to the right of the "throne" platform. It represents an ancient gate (gapura) with a flight of steps. The mood of this scene is sad; the dialogue takes place while the gender plays softly.

We see a female character wearing a silk kebaya and a batik jarik, her hair neatly arranged (cue: a princess) who enters through the gate and descends the stairs. She looks sad. Two ladies-in-waiting enter and keep her company. She appears to be Mas Ayu Asmarawati, Prince Mangkubumi's spouse (Image 5). She says she is worried since Prince Mangkubumi has not come home to the Mangkubumen for quite a long time; she does not know why and wonders what she has done wrong. Dispute between Menur and Telasih, her ladiesin-waiting, when Menur suggests he has taken a concubine. They complain about men's behaviour to women; suggestion to ask Prince Mangkubumi's mother what has happened. After having been informed, Mas Ayu Tejawati advises her daughter-in-law not to worry.

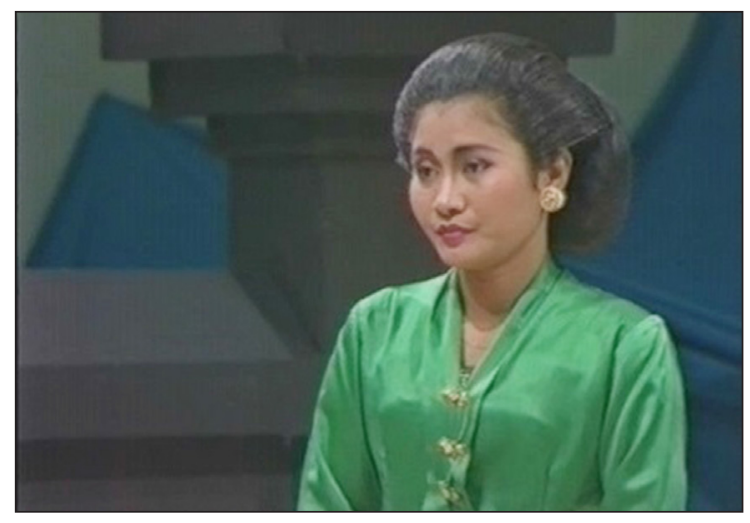

Image 5. Mas Ayu Asmarawati.

Suddenly, Ki Rangga enters (in laku dhodhok, accompanied by gamelan music). Mas Ayu Tejawati tells him about Mas Ayu Asmarawati's burden. This 
prompts him to tell the ladies the actual whereabouts of Prince Mangkubumi, who is driven by a high ideal (temen-temen mengku panjangka luhur), his concern for the people, and his determination to oust the Dutch from Java.

In a question and answer dialogue, bit by bit we obtain further details. When Mas Ayu Asmarawati asks him how he knows all this, Ki Rangga answers: It happened as follows (Menika wau rak ngaten). "How?", asks the princess. Ki Rangga recalls his meeting with Prince Mangkubumi at the outer gateway of the Mangkubumen. "What happened then?", asks the princess. He told me that he had just paid a visit to Ngersa Dalem Ingkang Sinuwun Paku Buwana ing Surakarta, continues Ki Rangga. Upon these last words, the gamelan plays loudly. The camera view gives us a medium close-up of Raden Rangga who, looking in what is meant to be the direction of Surakarta, with his thumb points in that direction.

The flashback begins when the medium close-up of Ki Rangga switches to a medium close-up of Prince Mangkubumi in the same pose, but his eyes cast down in awe of the Susuhunan (Images 6 and 7).

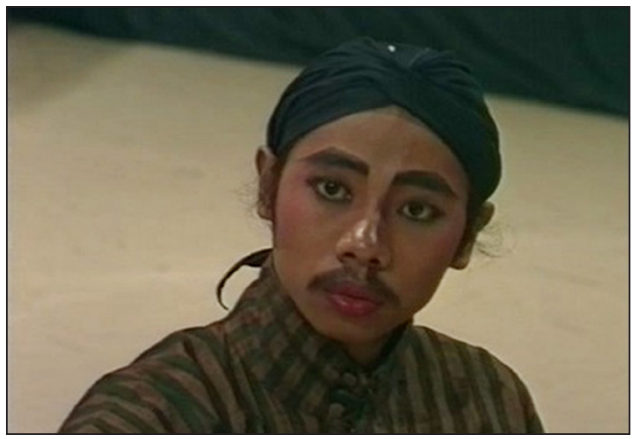

Image 6. Ki Rangga.

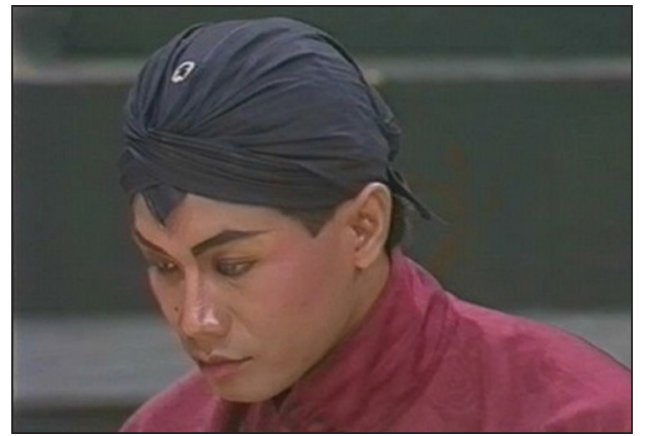

Image 7. Prince Mangkubumi.

The flashback brings us to the palace of the Susuhunan and depicts the meeting between the Susuhunan and Pangeran Mangkubumi. From the medium closeup of Pangeran Mangkubumi, the camera zooms out to a full shot: we see Mangkubumi seated cross-legged in front of the throne. He makes a sembah as the Sunan enters. To support the tense atmosphere, a contemporary gamelan composition accompanies the dialogue.

The Susuhunan tells Mangkubumi he has been awaiting his visit. He informs him about the important meeting in the audience hall, the visit of the GovernorGeneral and about the treaty (serat perjanjen) with the Dutch he has signed. Mangkubumi repeats his last words "Serat perjanjen!?". Very staccato and loud gamelan sounds express Mangkubumi's shock and horror upon hearing these words. He asks the Sunan about the contents of the agreement. The Susuhunan expounds the five points of the agreement and admits that he has already signed it at the instigation of Pringgalaya. Mangkubumi does not react, a close-up of his face, his eyes looking down, shows he is thinking. 
Eventually it becomes clear to him that Pringgalaya is the evil genius behind all this (meanwhile the pulsing gamelan heightens the tension). Had the Sunan requested him to return two-thirds of the land of Sokawati, he would surrender it entirely. But, realizing that Pringgalaya's wish is the desire of the Dutch, he decides to keep the grant, to stand up against the Dutch and expel them from Surakarta. The monarch now understands the error he committed and admits that Mangkubumi is right (Bener, bener, sira Dhimas).

This development in the narrative leads to the king praising Mangkubumi and supporting him. Mangkubumi thanks him and promises not to rebel against his half-brother. The Sunan asks him to wait for a moment, as he will give Mangkubumi sangu, things taken on a journey as supplies ${ }^{26}$ (Yen ngono Dhimas entenana sakwetara. Ingsun bakal paring sangu marang sliramu).

The flashback ends with a cliff-hanger, leaving the audiences waiting anxiously to discover the contents of the sangu. The camera brings us back to Ki Rangga relating what happened to the women in the female quarters of the Mangkubumen. Soft flute and gender music indicate the change in mood.

Mas Ayu Asmarawati wonders whether her husband will succeed in his plans. Ki Rangga: Certainly, as he is not only fighting for himself, but for the people. Besides - here follows a story about a dream Kangjeng Ratu Ageng, the wife of Ingkang Sinuwun Amangkurat Jawi, once had. Mangkubumi ate half of the moon; Raden Mas Said was about to eat the other half, but after he had only eaten half of the half of the moon, Kangjeng Ratu Ageng suddenly awoke. Mas Ayu Asmarawati enquires about the sangu which the Sunan gave to Prince Mangkubumi.

Ki Rangga: It was like this, Mas Ayu (Menika ngaten Mas Ayu). He tells about the Sunan returning, carrying a pusaka, a royal heirloom in the form of a lance (tumbak) in each hand. Narrating this, the camera fades out and focuses on the two lances. The gamelan plays loudly.

The second flashback returns to the dialogue between the Susuhunan and Pangeran Mangkubumi in the audience hall of the palace.

The Susuhunan offers Mangkubumi a choice between the two pusaka and gives him money. Mangkubumi chooses the lance the Sunan is holding in his left hand, accompanied by a male voice singing (gerongan), enhancing the dramatic effect of the situation. The Sunan praises Mangkubumi for his choice. While offering him the lance, he urges him to accept it and mentions its name: Kyai Plered (Age tampanana tombak pusaka [...] Kyai Plered). And stresses he should not postpone his plans too long.

Mangkubumi leaves in laku dhodhok. The camera zooms in to a medium shot of the Susuhunan, followed by a fade out which marks the end of the flashback.

In the Keputren, Ki Rangga addresses both women, concluding his account: This is what happened, Mas Ayu, as the Prince told it to me (Inggih ngaten 
menika Mas Ayu lelampahan ingkang dipun-ngendikakaken Njeng Pangeran dhateng kula). Upon which Mas Ayu Asmarawati says there is no longer any reason to be sad. A fade in of the camera depicts the arrival of Prince Mangkubumi. This is his first appearance seen from the perspective of the main storyline, as before he has just been mentioned in the discussions in the audience hall and shown in the flashbacks. His wife kneels before him to make him an obeisance with a sembah, but Mangkubumi swiftly helps her to rise to her feet. He explains his plans to Raden Rangga and orders him to put everything into order (tata-tata) and prepare for the war (yudha). He requests the two women to go to the princely lodge in Sokawati. The gamelan cues the end of this scene.

The cliff-hanger just mentioned is a narrative technique to keep the audiences alert. Another cliff-hanger occurs at the end of the first episode. When male and female soldiers in Grobogan are preparing for the war, suddenly a woman arrives, her fist raised. Leaving us with questions, rousing our curiosity, making us look forward for the second episode. In it we learn that she is Nyi Martapura, Ki Martapura's wife. She has become angry upon seeing the military training, assuming he is planning another revolt. A dispute with her husband follows. She realizes that her interpretation of and reaction to the situation was wrong and promises to join him in the war (Kula badhe tumut perang). According to director Bondan Nusantara, Nyi Martapura represents a strong woman. In this scene, the director aimed to actualize human rights. He said, in the past, Javanese society tended to be very paternalistic. Kethoprak should show a development, parallel to the evolution of contemporary society. Nyi Martapura's role contains Bondan's personal social criticism, ${ }^{27}$ which imbued the performance with extra meaning.

Music has several functions in the show. For example, a marching band escorts Governor-General van Imhoff to the Surakarta palace. Gamelan music evokes the mood in each scene and sequence and accentuates the strong emotions of the personages. At one point in the first scene, while the camera focuses on Governor-General van Imhoff who is entering the audience hall, we hear the sound of the kemanak, a pair of banana-shaped bronze instruments (Kunst 1973: 180-182; Brakel 1992: 36-37; 39). To the audiences, this sound indicates that a bedhaya dance is about to be performed. Indeed the next images show the bedhaya dancers entering the space from several camera angles (Image 8). After Mangkubumi's installation on the throne, the royal enthronement music is played. The music is also an essential accompaniment to the fighting scenes and the dances. 


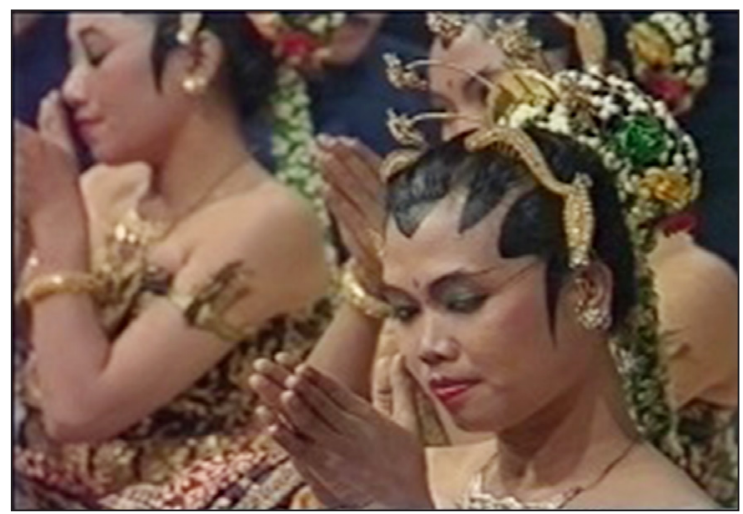

Image 8. Bedhaya dancers making the sembah.

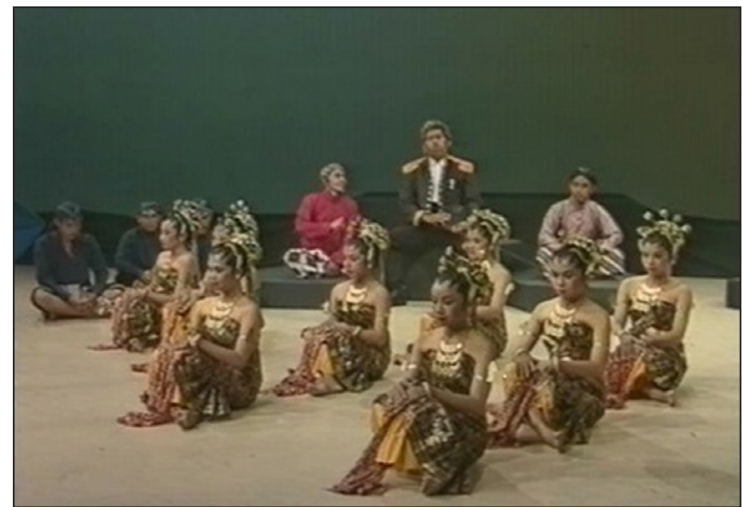

Image 9. Pringgalaya and Van Imhoff discuss the bedhaya dance.

The dances in the show function as entertainment. In the first scene, Governor-General van Imhoff is welcomed to the audience hall with a bedhaya dance. Just before the final scene, when battles are done, another dance genre is presented. Three female dancers perform a tayuban, inviting the soldiers who need a rest after the war - to join them.

During the bedhaya dance there is a conversation between Van Imhoff speaking a simple kind of Javanese with a "foreign" accent, sometimes having difficulty finding the correct Javanese word or expression, and inserting Dutch words - and Patih Pringgalaya (Image 9). Pringgalaya explains to the Governor-General he is watching royal entertainment, a bedhaya, always performed by nine dancers, and that every Friday Kliwon they dance in his residence, the Kepatihan. When the Patih asks what kind of dances are performed to welcome guests in the Netherlands, the Governor-General answers "dansa". Pringgalaya wonders whether it would be possible to have the royal dance staged in the Netherlands. Actually this sequence within the first scene, seemingly a parody of a conversation between a foreigner who is visiting Java and a Javanese culture specialist, is not included in the 1993 palace performance script. This absence can be interpreted in several ways: the sequence could have been an improvisation which was developed during 
the rehearsals before the television recording. Or perhaps it was included in the script used for the TV studio performance and recording which I have not yet encountered.

The fighting scenes belong to the narrative; they are essential to the development of the narrative, present dramatic tension and offer the audiences entertainment. Battles are part and parcel of this type of kethoprak.

The development of the plot leads to the climax, presented in the last scene. The final part of the show is considered to be of the utmost importance to the history of Yogyakarta. All the dramatis personae are gathered in the Royal Lodge Ambar Ketawang. To the strains of loud gamelan music, the camera focuses on all those people present, taking their places in the space and making a sembah. Prince Rangga Wirasetika reads the villagers a declaration proclaiming that Prince Mangkubumi is to be installed as the first sultan of Yogyakarta, because the Sunan of Surakarta has abdicated his position, in response to pressure from the Dutch (no music; medium close-up of Ki Rangga, alternating with panning camera images of those present). The same titles as those borne by his royal ancestor Sultan Agung are bestowed on him and henceforth he will be called: Kangjeng Sultan Hamengku Buwana Senapati Ingalaga Ngabdurrahman Sayidin Panatagama Kalipatollah ingkang jumeneng kaping sepisan ing Ngayogyakarta Hadiningrat. ${ }^{28}$ When the gamelan begins playing the gendhing jumenengan, the royal enthronement music, all present assume the jengkeng, a kneeling position, to await the arrival of the king. Solemnly the sultan enters the audience hall, followed by a courtier carrying the tombak Kangjeng Kyai Plered and his female attendants (manggung) who carry the royal regalia. As the sultan is ascending the throne (Image 10), the people make a sembah to show their respect (camera: from a close-up of the sultan panning out to full view of the audience hall and all those present). We see the royal umbrella opening slowly - stage props also have a function in the development of the plot - , and the audiences know this signals that the equilibrium has been achieved. ${ }^{29}$ This brings me to the role of the audiences who actually know the story, the outcome, the genre kethoprak and all its conventions and deviations from these conventions better than the narrators in the play. This common ground on which the audiences and the producers meet enables the attainment of meaning.

28 His Highness the Sultan, Sustainer of the Universe, Ruler of the World, Servant of the Merciful, Lawgiver of Religion, Representative of God on Earth, the first ruler of Yogyakarta. In the 1993 palace performance script: Sepisan: Kangjeng Pangeran Mangkubumi sampun kaleksanan jumeneng Sunan ing dhusun Kabanaran kanthi jejuluk Sunan Kabanaran.

Kaping kalihipun: Awit saking lereh keprabon dalem ingkang Sinuwun Kangjeng Sunan Pakubuwono Surakarta mergi dipun peksa Kumpeni sarta adhedhasar Perjanjen Giyanti dinten menika Kangjeng Sunan Kabanaran arsa jumeneng nata jejuluk Kangjeng Sultan Hamengku Buwana Senapati Ingalaga Ngabdurrahman Sayidin Panatagama Kalipatollah ingkang jumeneng kaping sepisan ing Ngayogyakarta Hadiningrat.

The programme began with a camera close-up of a royal umbrella which was closed. 


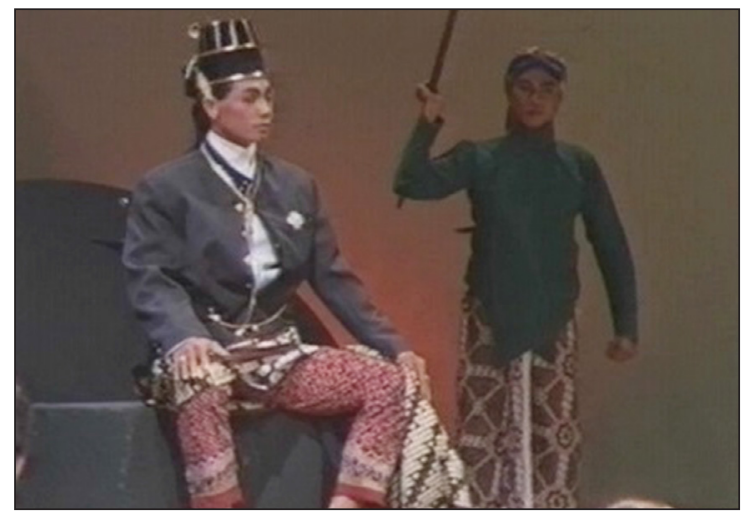

Image 10. Sultan Hamengku Buwana I on the throne.

\section{Intermediality: variations on a theme}

The purport and meaning of the 1993 TVRI Yogyakarta version of the enthronement of Prince Mangkubumi do not stand alone. This representation has been enriched by preceding live and mediated performances of the same story. As local nationalism in Yogyakarta is strong and its native inhabitants consider Sultan Mangkubumi a local hero, the lakon has always been popular and attracted large audiences from all layers of Yogyakartan society. It has been performed at various times by various groups and for various occasions and audiences, in villages, in a kraton environment by professional actors and elsewhere; up to the present it is still one of the most popular kethoprak plays. The performance history of a kethoprak story influences the perception of the audiences. This kind of watching is not genre specific - one is likely to compare the production one is watching to previous stagings, whether one watches kethoprak, opera or other performance genres. As becomes clear from Budi Susanto's study (2000: 127, 129), when watching a performance, the audiences discuss it making comparisons to other performances, basing their comments on their recollection of all the live, radio and television kethoprak performances they have listened to or watched previously. ${ }^{30}$ Moreover, comparing becomes easier when watching the various interpretations of one director and/or playwright. Bondan Nusantara, for instance, has frequently directed kethoprak plays with the Sultan Mangkubumi theme. ${ }^{31}$ While the plot and the central theme remain unchanged, each of these performances is adapted to the performance context. When, for instance, workers of the Amigo Grup in 2004 performed Mangkubumi wisudha in Wonosari, Gunungkidul, the director Bondan Nusantara adapted the language use in the dialogues to the circumstances. As the play was performed in a village context, the informal

30 "menonton berdasar ingatan (bukan pemahaman) dari tontonan-tontonan yang pernah ditonton sebelumnya" (Susanto 2000: 129).

31 In October 2007, the lakon was again performed in the Kraton Yogyakarta, this time entitled Adeging Kraton Ngayogyakarta (Pangeran Mangkubumi). The performance was again based on a script by Handung Kus Sudyarsana in a version reworked by Bondan Nusantara, and adapted to the new context (Script kindly provided by Bondan Nusantara). 
speech styles ngoko and krama madya prevailed over the very polite basa. ${ }^{32}$

Very probably, Kus Sudyarsana's kethoprak staging of the story of Mangkubumi's installment on the throne has been very influential. As a playwright, actor and director, Kus Sudyarsana was considered an important innovator of the kethoprak genre. In the early $1970 \mathrm{~s}^{33}$ he conceived a script for the newly founded Ketoprak Mataram Sapta Mandala Kodam VII Diponegoro, ${ }^{34}$ a kethoprak troupe of which his elder brother Bagong Kussudihardja was the leader. ${ }^{35}$ One of the aims of the group was to renew kethoprak continuously, not only on the artistic level, but also on the levels of the artists themselves and the organization (Kus Sudyarsana 1989:36-39). The story was performed live, using Kus Sudyarsana's script. Later, around 1975, entitled Hamengku Buwana I, it was recorded on cassette tape. Famous kethoprak artists performed the main roles: Widayat was Prince Mangkubumi, Marsidah played Rara Ayu Asmarawati and Marjiyo the role of Sunan Paku Buwana II. The play was shaped according to the constraints of the medium: it was condensed to fit the restricted time available and focused on the oral conveying of the story, devised to evoke it visually in the minds of the listeners. Although some sequences and the presentation do differ, the development in the plot corresponds largely to the 1993 TVRI version. Mangkubumi himself, for instance, tells his spouse how he obtained the lance Kangjeng Kyai Plered from Sunan Paku Buwana II, instead of Ki Rangga Wirasetika telling Mangkubumi's narration in two flashbacks. And it is not Governor-General Van Imhoff who visits Susuhunan Paku Buwana II but Baron von Hohendorff, the Governor of Java's Northeast Coast. A detailed comparison with the 1993 TVRI Yogyakarta version would reveal interesting parallels and differences, and show the influence of the media constraints on both versions. This recording on two cassette tapes must have been broadcast regularly by local Javanese TVRI and private radio stations. And, when bought by kethoprak aficionados, regularly enjoyed at home.

Another influential performance of the play which might have contributed to the collective memory and the way in which audiences watch kethoprak performances of this theme, is the 1993 performance in the Yogyakarta kraton. Just like the 1993 Yogyakarta TVRI version, it was based on a script by Kus Sudyarsana in a reworked version by Bondan Nusantara. ${ }^{36}$ In the words of Hatley (2008: 169), this performance in the sultan's palace "conveyed a sense of grandeur and solemnity but also presented fast-moving drama" - large battle scenes alternated with more reflexive sections on Mangkubumi's obligations as

32 Oral communication Bondan Nusantara July 2012; Naskah ketoprak kolosal; Mangkubumi wisudha, kindly provided by Bondan Nusantara.

33 Written communication Bondan Nusantara, May 2016.

34 The founding of the group was sponsored by the military Kodam VII/Diponegoro, later to become Kodam IV.

35 Also spelled Kussudihardjo.

36 The script to which I am referring in my exploration in this article (which I call "the 1993 palace performance script") was probably used to stage the 1993 performance in the Yogyakarta kraton. 
a responsible king and his close relationship with the people (Hatley 2008: 169).

Mediated productions of performative arts certainly contribute to the growth of the collective memory. One example is to be found in recently published weblogs which refer to past kethoprak broadcasts of TVRI Stasiun Yogyakarta and Surabaya. Besides showing how popular these broadcasts were in the nineteen nineties, the blogs also connect them to a feeling of nostalgia.

Further research on the performance history would be interesting. It could reveal the different interpretations of the story, the adaptations to the performance context and to the social and political context of the time, the influence of the patron who commissioned the performance and so on. And it would show how, by putting together works which have an intermedial relationship, these strengthen each other's meaning (Djoharnurani 1999: 1011). ${ }^{37}$

Another form of intermediality is to be found in the fact that the story about Prince Mangkubumi is part of a much larger story told in the Javanese babad literature in such works as the Babad Giyanti and the Babad Tanah Jawi, and in oral stories relating the history of Mataram and Yogyakarta. To prepare for the performance, playwright and director Bondan Nusantara not only used Kus Sudyarsana's script, which is related to this babad literature; he also consulted academic studies to form a better image of the historical events and the protagonists' characters. Among the works consulted were M.C. Ricklefs' Yogyakarta under Sultan Mangkubumi (1974), K.P.H. Soedarisman Poerwokoesoemo's Kadipaten Pakualaman (1985) and Daerah Istimewa Yogyakarta (1984) and Sartono Kartodirdjo's writings. Hampered by bureaucratic obstacles and a lack of time Bondan Nusantara acknowledged he was unable to consult court manuscripts. ${ }^{38}$

The parallels between the 1993 TVRI Yogyakarta version of Prince Mangkubumi's installation and stories about both Mangkubumi's predecessors and descendants again show another kind of intermediality.

The "life and exploits" (Pigeaud 1967: 161) of Sultan Agung, who ruled over the Central Javanese kingdom Mataram from 1613 until 1646, are described in the Serat (or Babad) Nitik Sultan Agungan. ${ }^{39}$ In this instance of storytelling, oral and written traditions have merged: The Nitik Sultan Agungan are based on orally transmitted folk stories, the texts written in Javanese verse, tembang macapat, contain features of orality, and their performance is again oral. The actual telling of the story in performance consists of a recital of the text before an audience; the performer keeps to the wording of the text, and 'sings' according to the mood prescribed by the character of the various cantos.

In the Nitik Sultan Agungan we are told how Sultan Agung miraculously

37 Djoharnurani refers to Morris and Steiner, and Morris' reaction to Steiner.

38 Oral communication Bondan Nusantara, July 2012.

39 In this article further referred to as Nitik Sultan Agungan. See Bogaerts 1990 for a detailed analysis of the various recensions of the Nitik Sultan Agungan. 
conquers the surrounding regions of Mataram as well as converts their inhabitants to Islam; how he acquires secret knowledge; and how he falls in love with Ratu Kidul, the Queen of the Southern Ocean. The sultan's conflicts with the Dutch and his bond with Ratu Kidul are particular themes which recur in the various poetic versions of the story. The queen, impressed by Agung's excellence, decides to give him royal titles, calling him not only Ruler of the World (Senapati Ingalaga), but also Lawgiver of Religion (Sayidin Panatagama) and Representative of God on Earth (Kalipatullah). ${ }^{40}$ The titles give the sultan a new status and both secular and spiritual power. This mythical support for Sultan Agung as a historical figure will be inherited by all future Javanese kings up to the present, including Prince Mangkubumi. The stories were and are told to legitimize kingship. Therefore they refer to relevant historical facts. Ample attention is paid to the special qualities a future king should possess. These include an appropriate genealogy, charisma and invincibility, and religious support from Hindu-Buddhist and/or Islamic side (Ras 1994: 534-535). The king should also have the royal heirlooms in his possession and therefore the enrapturing music and dance performed in Ratu Kidul's underwater palace are made into royal entertainment, named Bedhaya Semang and Gamelan Sekati by Sultan Agung. A comparison of the performance of Javanese history in the Nitik Sultan Agungan with kethoprak representations such as the Sragen performance to which I referred at the beginning of this article could yield interesting information on the processes of intermediality.

Sultan Hamengku Buwana IX is another historical figure of the Mataram dynasty who has been put on stage as a character. In Sang Prawara, a creation of RM Kristiadi (1993), Sultan Hamengku Buwana IX's life and exploits were presented in a dance drama (sendratari). The story was evoked by movement and sound (both sung and played on the gamelan), while the performance was based on a contemporary script. All the sultan's important achievements received attention in the performance, especially his contribution to Yogyakarta and the nation during the struggle for independence against the Dutch. In particular, the sultan was put on stage as a hero, participating in the glory of his predecessors (Pigeaud 1967: 161), Sultan Agung and Prince Mangkubumi.

At the Yogyakarta Art Festival (Festival Kesenian Yogyakarta, FKY) in 2011 Sultan Hamengkubuwana IX was once more put on stage, this time in a colossal kethoprak performance entitled Alive or dead; The history of Yogyakarta as the capital of the Indonesian Republic (Merdeka atau mati; Sejarah Yogya sebagai ibukota RI). The Young Kethoprak Generation of Yogyakarta (Generasi Muda Ketoprak Yogya) staged the play under the direction of Bondan Nusantara, based on a script by Ari Purnomo and Bondan Nusantara. ${ }^{41}$

Although based on written texts, all the examples of storytelling I have mentioned here, including those broadcast on radio and television, are oral. It is the oral character of the performances which facilitates and enhances the various kinds of intermediality I have explored in this article.

$40 \quad$ See Bogaerts 1990: 81-82, 152.

41 Script kindly provided by Bondan Nusantara. 


\section{CONCLUSIONS}

The representation of history in performance plays an important role in the branding of the Special Region of Yogyakarta. It legitimizes the power of the rulers of Mataram/Yogyakarta and strengthens the identity of the city and its inhabitants. The audiences know the stories and that is part of the fun.

The example of the Yogyakarta TVRI broadcast Pangeran Mangkubumi wisuda reveals the intricate relationship between the written and the spoken word: the written script, based on both oral and written traditions, is actually presented in the oral performance. It also reveals how the narrative is told by means of performative and televisual techniques. Performative aspects and the edited results of the camera and sound recordings combine to determine how the story is narrated; they affect the perspectives and angles and create the tempo of the narrative. They determine what we hear and see and how we do so: the setting; the personages and how they relate to each other in dialogues, movement, body language; the music and other sounds; the stage props; the development of the plot. As the televised performance is oral, aural and visual in character, it is essential to take into account when studying oral traditions.

Kethoprak is perceived as an expression of Javaneseness and as a great culture inherited from the past, but nonetheless enjoyed as entertainment. The kethoprak play Pangeran Mangkubumi wisuda has been performed for many decades and still remains a favourite, as my first example at the beginning of this article shows. In 2014, the kraton sponsored a new serialized version of the lakon produced and broadcast by the local television station TVRI Jogja. ${ }^{42}$

Variations on the script by Kus Sudyarsana in versions reworked by Bondan Nusantara have led to a wide range of variant performances. Adapted to the performance context and to the dynamics in society, the performing of the story also offers the possibility to rephrase (rather than rewrite) history in order to make historical events fit Javanese ideology. Consequently, the performances give an insight not only into past histories, but also into the circumstances prevailing at the time of performance.

The intermedial character of stories about Prince Mangkubumi, Sultan Agung and other Mataram heroes influences the audiences' perception and reception. These stories cross not only different media, they also bestride time and space: from the nineteenth-century poetic tembang macapat to presentday interpretations of tembang in Hip Hop versions, from kethoprak plays in Javanese to serialized historical films in Indonesian. They also occur in print literature in Indonesian and in Wikipedia articles. They are performed in Yogyakarta, Sragen, and all over Java (and other locations where Javanese is spoken), and to this very date disseminated to the areas within reach of the radio and television stations.

The storytelling inspired by Sultan Agung and Prince Mangkubumi continues... 


\section{PRIMARY SOURCES}

SCRIPTS

Kus Sudyarsana, Handung. [Nd.]. "Naskah kethoprak lampahan Pangeran Mangkubumi wisuda". Reworked by Bondan Nusantara.

Nusantara, Bondan. 2004. "Naskah kethoprak kolosal Mangkubumi wisudha". Reworked version of a script by Handung Kus Sudyarsana. Performed by workers of the Amigo Group.

Nusantara, Bondan. 2007. “Adeging Kraton Ngayogyakarta (Pangeran Mangkubumi)“. Script by Handung Kus Sudyarsana in a version reworked by Bondan Nusantara.

Nusantara, Bondan. 2011. “Naskah ketoprak kolosal Merdeka atau mati; Sejarah Yogya sebagai ibukota RI". Script by Bondan Nusantara.

\section{TELEVISION PROGRAMME}

Sekber Unit Kesenian UGM Yogyakarta. 1993. Pangeran Mangkubumi wisuda. A production of TVRI Stasiun Yogyakarta. Script: Handung Kus Sudyarsana, Director: Bondan Nusantara, Producer: Supranyata. Broadcast on 20 September and 11 October 1993.

\section{CASSETTE RECORDING}

Keluarga Ketoprak Mataram Kodam VII Diponegoro. [1976]. “Ketoprak Mataram Hamengku Buwana I". Lokananta ACD-113/A-B. [2 cassette tapes.]

\section{LIVE PERFORMANCE}

Kristiadi, RM. 1993. Sang Prawara. Sendratari, performed at the Kepatihan, Yogyakarta. [Personally witnessed, October 1993.]

\section{REFERENCES}

Bauman, R. 1984. Verbal art as performance. Rowley, MA: Newbury House Publishers.

Bauman, R. 1992. "Performance", in: R. Bauman (ed.), Folklore, cultural performances, and popular entertainments; A communications-centered handbook, pp. 41-49. New York / Oxford: Oxford University Press.

Bogaerts, Els. 1990. "Van Sunans, sultans en sultanes; Nyai Lara Kidul in de Panitik Sultan Agungan". MA thesis, Leiden University.

Bogaerts, Els. Forthcoming. "Mediating the local; Representing Javanese cultures on local television in Indonesia", Journal of Southeast Asian Studies.

Bosnak, Judith. 2006. Shaping the Javanese play; Improvisation of the script in theatre performance. PhD thesis, Leiden University.

Brakel-Papenhuyzen, Clara. 1992. The bedhaya court dances of Central Java. Leiden: Brill.

Brandon, James R. 1974. Theatre in Southeast Asia. Cambridge, MA: Harvard University Press. [First printing: 1967.] 
Chapple, Freda and Chiel Kattenbelt. 2006. "Key issues in intermediality in theatre and performance", in: Freda Chapple and Chiel Kattenbelt (eds), Intermediality in theatre and performance, pp. 11-25. Amsterdam/New York: Rodopi.

Chatman, Seymour. 1990. Coming to terms; The rhetoric of narrative in fiction and film. Ithaca, NY: Cornell University Press.

Djoharnurani, Sri. 1999. "Seni dan intertekstualitas; Sebuah perspektif. Yogyakarta: Institut Seni Indonesia“. [Academic speech, Dies Natalis XV Institut Seni Indonesia, Friday, 23 July 1999.]

Finnegan, Ruth. 1992. Oral traditions and the verbal arts; A guide to research practices. London/New York: Routledge.

Hatley, Barbara. 1981. "Babads on stage: Javanese history and contemporary popular theatre", Indonesia Circle 26 (November): 33-43.

Hatley, Barbara. 1985. Kethoprak - Performance and social meaning in a Javanese popular theatre form. PhD thesis, University of Sydney.

Hatley, Barbara. 2004. "Global influence, national politics and local identity in Central Javanese theatre", RIMA; Review of Indonesian and Malaysian Affairs 38/2: 63-99.

Hatley, Barbara. 2005. “Theater, politics, and Javanese 'tradition'; Yogyakarta's sultan onstage", in: Hans Antlöv and Jörgen Hellman (eds), The Java that never was; Academic theories and political practices, pp. 67-96. Münster: LIT.

Hatley, Barbara. 2008. Javanese performances on an Indonesian stage; Contesting culture, embracing change. Leiden: KITLV Press.

Kayam, Umar, Ahmad Adaby Darban, Ryadi Gunawan, and Faruk. 1985/1986. Beberapa bentuk seni tradisional Jawa. Yogyakarta: Departemen Pendidikan Kebudayaan, Direktorat Jendral Kebudayaan, Direktorat Sejarah dan Nilai Tradisional, Proyek Inventarisasi dan Dokumentasi Kebudayaan Daerah.

Kayam, Umar, et al. 2000. "Pertunjukan rakyat tradisional Jawa dan perubahan", in: Heddy Shri Ahimsa-Putra (ed.), Ketika orang Jawa nyeni, pp. 339-396. Yogyakarta: Galang Press. [This is a reworked version of the research report by Kayam et al. 1985/1986.]

Kozloff, Sarah. 1992. "Narrative theory and television", in: Robert C. Allen (ed.), Channels of discourse, reassembled; Television and contemporary criticism, pp. 67-100. London: Routledge.

Kunst, J. 1973. Music in Java; Its history, its theory and its technique. Vol. I. The Hague: Martinus Nijhoff. [Third, enlarged edition, edited by E.J. Heins.]

Kus Sudyarsana, Handung. 1984/1985. “Kethoprak kelilingan”, in: Soedarsono, Djoko Soekiman, and Ratna Astuti (eds), Gamelan, drama tari dan komedi Jawa, pp. 59-81. [Yogyakarta:] Proyek Penelitian dan Pengkajian Kebudayaan Nusantara (Javanologi), Direktorat Jendral Kebudayaan, Departemen Pendidikan dan Kebudayaan.

Kus Sudyarsana, Handung. 1989. Ketoprak. Yogyakarta: Kanisius.

Kus Sudyarsana, Handung and Bondan Nusantara. 1990. Unggah-ungguhing basa ing kethoprak lan kethoprak in televisi. Yogyakarta: Taman Budaya. Yogyakarta and Kethoprak Sapta Mandala Kodam IV Diponegoro Yogyakarta, in cooperation with Harian Terbit Jakarta. 
Lephen P. 1991. "Ing jagad kethoprak Rama Handung pawang mendhung", Mekar Sari XXXV-07 (17 April): 32-33.

Lindsay, Jennifer. 1997. "Making waves; Private radio and local identities in Indonesia", Indonesia 64: 105-123.

Mardianto, Herry and Antonius Darmanto. 2001. Tradisi sastra Jawa radio. Yogyakarta: Kalika.

MS. 1991a. "Marisi semangat lan trajange Rama Ndung", Mekar Sari XXXV04 (27 March): 3.

MS. 1991b. "Handung Kus Sudyarsana; Seniman nyleneh sarwa nalar iku wis tinggal donya", Mekar Sari XXXV-04 (27 March): 8-9.

MS-Warso Sastrosuwarno. 1991. "Sugeng tindak Mas Handung”, Mekar Sari XXXV-04 (27 March): 9.

Nusantara, Bondan. 1990. "Kethoprak ing televisi", in: Handung Kus Sudyarsono and Bondan Nusantara, Unggah-ungguhing ing basa kethoprak; Kethoprak ing televisi, pp. 39-69. Yogyakarta: Taman Budaya Yogyakarta and Kethoprak Sapta Mandala Kodam IV Diponegoro, in cooperation with Harian Terbit Jakarta.

Nusantara, Bondan. 1991. "Ngrembag perkawis kethoprak televisi (IV)", Mekar Sari XXXIV-51 (20 February): 42.

Pigeaud, Theodore Th. G. 1967. Literature of Java; Catalogue raisonné of Javanese manuscripts in the library of the University of Leiden and other public collections in the Netherlands. Volume I: Synopsis of Javanese literature 900-1900 A.D. The Hague: Martinus Nijhoff.

Poerwokoesoemo, K.P.H. Soedarisman. 1984. Daerah Istimewa Yogyakarta. Yogyakarta: Gadjah Mada University Press.

Poerwokoesoemo, K.P.H. Soedarisman. 1985. Kadipaten Pakualaman. Yogyakarta: Gadjah Mada University Press.

Ras, J.J. 1994. "Geschiedschrijving en de legitimiteit van het koningschap op Java", Bijdragen tot de Taal-, Land- en Volkenkunde 150/3: 518-538.

Ricklefs, M.C. 1974. Jogjakarta under Sultan Mangkubumi, 1749-1792; A history of the division of Java. London: Oxford University Press.

Robson, Stuart and Singgih Wibisono, with the assistance of Yacinta Kurniasih. 2002. Javanese-English dictionary. Singapore: Periplus.

Scannell, Paddy. 1995. "For a phenomenology of radio and television", Journal of Communication 45/3 (Summer): 4-19.

Schechner, Richard. 1993. The future of ritual; Writings on culture and performance. London: Routledge.

Sedyawati, Edi. 1981. Pertumbuhan seni pertunjukan. Jakarta: Sinar Harapan.

Soedarsono, R.B. 1993. "Mangkubumi wisuda, ketoprak monumental", Kedaulatan Rakyat (18 January): Front page.

Susanto, Budi S.J. 2000. Imajinasi penguasa dan identitas postkolonial. Yogyakarta: Kanisius.

Sutton, A.R. 1985. "Commercial cassette recordings of traditional music in Java; Implications for performers and scholars", The World of Music 27/3: 23-45.

Tan Sooi Beng. 1997. Bangsawan; A social and stylistic history of popular Malay opera. Penang/Kuala Lumpur: The Asian Centre. 
Utami. 1993. "Wicaksono Haryo Putro: Penari Kraton dan Ketoprak", Kedaulatan Rakyat (Saturday, 25 September): 11.

Vaníčková, E. 1965. "A study of the Javanese ketoprak", Archiv Orientální33: 397-450. [Praha: Czechoslovak Academy of Sciences.]

Widodo, Agung. 2015. "Drama kolosal Pangeran Mangkubumi awali upacara kemerdekaan". [Retrieved from: http://www.timlo.net/ baca/68719633873/drama-kolosal-pangeran-mangkubumi-awaliupacara-kemerdekaan/(17 August), last accessed on 14-12-2015.]

Wijaya and F.A. Sutjipto. [1977]. Kelahiran dan perkembangan ketoprak; Teater rakyat Jawa Tengah dan Daerah Istimewa Yogyakarta. Yogyakarta: Proyek Pembinaan Kesenian, Direktorat Pembinaan Kesenian, Direktorat Kebudayaan Departemen Pendidikan dan Kebudayaan.

Williams, Raymond. 1994. Television; Technology and cultural form. Edited by Ederyn Williams. London: Routledge. [First edition: 1975.]

Wolf, Werner. 1999. The musicalization of fiction; A study in the theory and history of intermediality. Amsterdam: Rodopi.

Yudha SJ. 2015a. “Seniman Ketoprak RRI Yogyakarta pentaskan 'Kembang Wijayakusuma'". [Retrieved from: http://sorotjogja.com/yogyakartapentaskan-wijayakusuma/ (5 May), last accessed on 9-2-2016.]

Yudha SJ. 2015b. "Malam ini pentas ketoprak 'Kembang Wijayakusuma' tamat". [Retrieved from: http://sorotjogja.com/ketoprak-kembangwijayakusuma/ (3 June), last accessed 9-2-2016.]

Yuliantri, Rhoma Dwi Aria and Muhidin M. Dahlan. 2008. Lekra tak membakar buku; Suara senyap lembar kebudayaan Harian Rakjat 1950-1965. Yogyakarta: Merakesumba. 